\title{
Nekton use of vegetated marsh habitats at different stages of tidal inundation
}

\author{
R. T. Kneib, S. L. Wagner \\ The University of Georgia Marine Institute, Sapelo Island, Georgia 31327, USA
}

\begin{abstract}
Fishes and crustaceans are potentially important vectors for the transfer of production from intertidal marshes to subtidal estuarine environments. Because marsh habitats are accessible to nekton only when tidally inundated, understanding variation in habitat use associated with the tidal cycle is crucial for estimating the magnitude of production transfers attributable to nekton populations. We compared species richness, abundance and size distributions of nekton on incoming, slack high and ebbing stages of spring tides at 2 vegetated intertidal marsh sites $(25$ and $90 \mathrm{~m}$ from the nearest tidal creek) on Sapelo Island, Georgia, USA. The findings showed how use of an intertidal marsh by nekton varied on temporal and spatial scales pertinent to understanding salt marsh community and ecosystem dynamics. A total of 9627 individuals distributed among 17 species of fishes and 4 species of decapod crustaceans were collected from 60 samples of $100 \mathrm{~m}^{2}$ each during June to August 1991. The cyprinodontids Fundulus heteroclitus and F. luciae accounted for $90.2 \%$ of all fishes; caridean Palaemonetes pugio and penaeid Penaeus setiferus shrimps composed $99.8 \%$ of the decapod crustaceans. In general, nekton abundance and species richness were greatest at slack high tide. In contrast to the depth distribution patterns usually observed at low tide, most of the smaller size classes of nekton that used the vegetated marsh at high tide were in the deeper site nearest the creek while larger size classes penetrated farther into the marsh interior The amount of intertidal marsh production transfered to subtidal estuarine habitats by different species of nekton may depend on how each responds, on balance, to the expanded foraging opportunity presented when the marsh floods and the risk of being stranded in the intertidal zone when the tide ebbs.
\end{abstract}

KEY WORDS: Production transfers Tide stage - Intertidal marshes - Fishes - Decapod crustaceans Habitat use

\section{INTRODUCTION}

Vegetated habitats are focal points for populations of fishes and crustaceans within estuaries. Nekton standing stocks usually are many times greater in or near seagrass beds (Heck \& Thoman 1984, Ferrell \& Bell 1991), mangroves (Robertson \& Duke 1987, Morton 1990) and tidal marshes (Zimmerman \& Minello 1984, Ayvazian et al. 1992) than in unvegetated habitats. Tidal, diurnal and seasonal migrations of species between vegetated estuarine habitats and other environments (McIvor \& Odum 1988, Parrish 1989, Baelde 1990) suggest the potential for important trophic connections among estuarine habitats (Weisberg \& Lotrich 1982, Ryer 1987) or between estuaries and other coastal environments (Flores-Verdugo et al. 1990, Dee- gan 19931. Understanding temporal, as well as spatial, variation in use of vegetated habitats by dominant species is clearly essential for defining the role of nekton in the movement of materials and energy within and from estuaries.

Factors affecting accessibility and foraging time in different vegetated habitats are likely determinants of nekton use patterns (Kneib 1984). Subtidal vegetation (e.g. seagrass beds) is always available to nekton, but access to intertidal vegetated habitats (e.g. marshes and mangrove forests) is restricted to periods of tidal inundation. Nekton associated with intertidal vegetation experience a foraging environment that regularly expands and shrinks with the flow and ebb of the tides. The incoming tide provides access to the high productivity of the intertidal habitat, but the ebbing tide car- 
ries the risk of stranding (Gibson 1988). What species and size classes of nekton take advantage of foraging opportunities in vegetated intertidal habitats? How far do nekton penetrate the vegetated intertidal zone? How long do they forage there before returning to other habitats? Sampling gear limitations can make simple questions like these difficult to address in structurally complex vegetated habitats.

Some gear, such as certain large drop samplers (e.g. Zimmerman \& Minello 1984), collect nekton only near the edge of intertidal vegetation. Other quantitative methods, such as flume nets (McIvor \& Odum 1986) and various block net techniques (e.g. Thayer et al. 1987, Hettler 1989, Morton 1990, Fitz \& Wiegert 1991), because they integrate information over space and time, provide little detail about the extent or duration of excursions by nekton into the vegetated intertidal. However, new methods (Kneib 1991, Rozas 1992) now offer ways to address previously intractable questions about use of vegetated intertidal habitats by nekton. We applied one of these methods, the flume weir (Kneib 1991), to study variation in nekton use of flooded intertidal marsh habitats at different tide stages. Fishes and crustaceans that move into the intertidal marsh early and leave late in the tide cycle maximize foraging time in this productive environment but face increased risk of being stranded the further they venture from permanent aquatic refuges (Gibson 1988). Our purpose was to determine how different species and size classes of nekton responded to the potential benefits and risks of foraging within the intertidal marsh by measuring species richness, relative abundance and size distributions at incoming, slack high and ebbing stages of tides flooding the vegetated marsh surface.

\section{METHODS}

Study area and physical characteristics. All samples were collected between 10 June and 13 August 1991 from a vegetated intertidal area $\left(31^{\circ} 29^{\prime} 30^{\prime \prime} \mathrm{N}, 81^{\circ} 15^{\prime}\right.$ $28^{\prime \prime} \mathrm{W}$ ) in the upper reaches of the Duplin River on the west side of Sapelo Island, Georgia, USA. The Duplin River, actually a tidal lagoon, is the principal drainage channel for ca $20 \mathrm{~km}^{2}$ of salt marsh (Wadsworth 1980). The marsh is inundated twice daily by unequal tides with a mean range of $2.1 \mathrm{~m}$. Most of the emergent marsh surface is between 1.8 and $2.2 \mathrm{~m}$ above mean low water (MLW) and dissected by a network of intertidal creeks (0.5 to $>2$ m deep) that channel the tidal flow until the marsh is inundated. Unvegetated tidal mudflats are a relatively minor areal component of the system.

We measured distances and relative elevations in the area using a surveying transit and stadia rod.
Depth of tidal inundation was measured by a Druck Model PDCR 10/D (175 mb) pressure transducer and recorded on an electronic datalogger (Model EL-824 Easylogger, Omnidata International, Inc.) at $10 \mathrm{~min}$ intervals from March 1988 to September 1990. The pressure transducer was not operational during the present study, but using the previously recorded tide data and survey measurements we estimated elevations relative to MLW at the intertidal sampling sites. The low site was ca $185 \mathrm{~cm}$ above MLW and $25 \mathrm{~m}$ horizontal distance from the nearest creek channel, the high site was ca $198 \mathrm{~cm}$ above MLW and $90 \mathrm{~m}$ from the creek.

Salinity, measured with an optical refractometer, ranged from 14 to $20 \%$ with a mean $( \pm$ SE) of $18.6 \pm$ $0.31(n=29)$. Mean $( \pm S E)$ daily air temperatures, based on hourly averages of measurements recorded at 10 min intervals on the electronic datalogger, ranged from $22.7 \pm 0.72^{\circ} \mathrm{C}(\mathrm{n}=24)$ to $29.1 \pm 0.73^{\circ} \mathrm{C}(\mathrm{n}=24)$ during the study. Smooth cordgrass Spartina alterniflora was the dominant emergent vegetation at both intertidal sites, but its growth form was shorter and stem density greater at the high site, where sea lavender Limonium carolinianum and glasswort Salicornia virginica were also present.

Sampling gear and design. Fishes and decapod crustaceans were captured in flume weirs (Kneib 1991) located at both intertidal sites. The flume weir provides a 'snapshot' sample of nekton from anywhere within the vegetated intertidal zone at any time during the period of tidal inundation. Briefly, the device consisted of a series of wooden support posts that defined a pentagon-shaped sampling area of $100 \mathrm{~m}^{2}$. When the marsh was flooded, nekton moved freely in or out of the sampling area from any direction. At the designated time in the tidal cycle, screen (1.2 $\mathrm{mm}$ square mesh) panels were inserted between the posts to completely enclose the sampling area. As the tide ebbed, nekton trapped within the flume weir moved to the apex of the pentagon-shaped sampling area where they were concentrated in 2 pits fitted with removable screen baskets. Nekton were collected from the baskets after the tide receded from the marsh surface. Kneib (1991) provided details on flume weir construction and operation.

We collected samples from both intertidal sites during incoming, slack high, and ebbing stages of the tide. For incoming and ebbing tide samples, the flume weir panels were set in place when the sampling area was flooded to a depth of $10 \mathrm{~cm}$ (i.e. rising to $10 \mathrm{~cm}$ on the incoming and falling to $10 \mathrm{~cm}$ on the ebbing). For slack high tide samples, panels were set at the peak of the high tide. Every elevation $\times$ tide stage combination was sampled twice during each of 5 weekly periods centered on the semi-monthly spring tides. This pro- 
Table 1. Dates (1991) and times (Eastern Standard Time, $24 \mathrm{~h}$ ) of flume weir samples for each combination of tide stage (incoming, slack high, ebbing) and intertidal site (low $=185 \mathrm{~cm}$ above mean low water, $25 \mathrm{~m}$ from creek; high $=198 \mathrm{~cm}$ above MLW,

$90 \mathrm{~m}$ from creek). "Sample taken between sunset and sunrise (night)

\begin{tabular}{|c|c|c|c|c|c|c|c|c|}
\hline \multicolumn{3}{|c|}{ Incoming } & \multicolumn{3}{|c|}{ Slack high } & \multicolumn{3}{|c|}{ Ebbing } \\
\hline \multirow[t]{2}{*}{ Date } & \multicolumn{2}{|c|}{ Time } & \multirow[t]{2}{*}{ Date } & \multicolumn{2}{|c|}{ Time } & \multirow[t]{2}{*}{ Date } & \multicolumn{2}{|c|}{ Time } \\
\hline & Low & High & & Low & High & & Low & High \\
\hline & & & & Week 1 & & & & \\
\hline 11 Jun & $06: 00$ & $06: 40$ & $10 \mathrm{Jun}$ & $06: 25$ & $06: 33$ & 13 Jun & $10: 35$ & $10: 10$ \\
\hline $16 \mathrm{Jun}$ & $10: 32$ & $11: 03$ & $15 \mathrm{Jun}$ & $11: 45$ & $11: 38$ & 14 Jun & $12: 00$ & $11: 28$ \\
\hline & & & & Week 2 & & & & \\
\hline 23 Jun & $16: 55$ & $17: 25$ & 25 Jun & $20: 20^{\mathrm{a}}$ & $20: 10^{\mathrm{d}}$ & 24 Jun & $22: 20^{a}$ & $21: 55^{\mathrm{a}}$ \\
\hline 28 Jun & $19: 50^{\mathrm{d}}$ & $20.23^{\mathrm{a}}$ & 29 Jun & $23: 15^{\mathrm{a}}$ & $23: 00^{\mathrm{a}}$ & 26 Jun & $23: 38^{t}$ & $23: 03^{\mathrm{a}}$ \\
\hline & & & & Week 3 & & & & \\
\hline $13 \mathrm{Jul}$ & $08: 00$ & $08: 25$ & $11 \mathrm{Jul}$ & $08: 31$ & $08: 25$ & $12 \mathrm{Jul}$ & $11: 21$ & $10: 56$ \\
\hline $14 \mathrm{Jul}$ & 09:02 & $09: 27$ & $15 \mathrm{Jul}$ & $11: 45$ & $11: 36$ & $16 \mathrm{Jul}$ & $15: 05$ & $14: 45$ \\
\hline & & & & Week 4 & & & & \\
\hline $25 \mathrm{Jul}$ & $18: 30$ & $19: 00$ & $23 \mathrm{Jul}$ & $19: 10$ & $19: 05$ & $26 \mathrm{Jul}$ & $22: 25^{\mathrm{a}}$ & $21: 55^{\mathrm{d}}$ \\
\hline $29 \mathrm{Jul}$ & $21: 00^{\mathrm{a}}$ & $21: 40^{\mathrm{a}}$ & $28 \mathrm{Jul}$ & $22: 03^{a}$ & $21: 57^{\alpha}$ & $27 \mathrm{Jul}$ & $23: 25^{\text {a }}$ & $23: 00^{a}$ \\
\hline & & & & Week 5 & & & & \\
\hline 9 Aug & $06: 09$ & $06: 40$ & $8 \mathrm{Aug}$ & 07:10 & $07: 03$ & $10 \mathrm{Aug}$ & $10: 40$ & $10: 15$ \\
\hline 13 Aug & $09: 25$ & $09: 55$ & $12 \mathrm{Aug}$ & $11: 03$ & $10: 54$ & 11 Aug & $11: 55$ & $11: 35$ \\
\hline
\end{tabular}

duced 10 temporal replicates of each combination for a total of 60 flume weir samples (Table 1). Within a given sampling period, we randomly assigned (using a random number table) the order in which the tide stages were sampled. Both day and night tides were included within the sampling program but these were not equally represented because days are longer than nights in the summer (ca $14 \mathrm{~h}$ light : $10 \mathrm{~h}$ dark) and so there was a greater chance of any particular tidal stage occurring during the day.

Statistical analyses. We used Version 4.01 of the statistical package SPSS PC+ (Norušis 1990) to perform the data analyses in this study. Additional details concerning any of the procedures can be found in Sokal \& Rohlf (1981). The principal factors of interest were tide stage (incoming, slack high, ebbing), intertidal site (low, high) and sampling week (10 to 16 June, 23 to 29 June, 11 to 16 July, 23 to 29 July, 8 to 13 August). The response variables were number of species (species richness), number of individuals (abundance) and size distribution of nekton in the samples. We considered abundances of the 4 dominant species separately, but pooled the rest of the nekton into a single category (all other species). We measured size as standard length (SL, tip of the lower jaw to end of the vertebral column) in fishes and total length (TL, tip of rostrum to end of telson) in shrimps.

Paired $t$-tests were used to compare species richness and abundances between intertidal sites because both sites were always sampled on the same tide. We pooled the total number of species collected at both sites on each sampling date and used a 2 -way analysis of variance (ANOVA) to test for the separate and interactive effects of tide stage and sampling week on species richness. A 3-way ANOVA tested for the separate effects and interactions of tide stage, intertidal site and sampling week on species abundances. When significant ( $F$-values associated with a probability of $\mathrm{p} \leq 0.05$ ) main effects were detected in the multifactor ANOVAs, the Student-Newman-Keuls procedure ( $\alpha=$ $0.05)$ was applied to determine which means differed from the others. Significant interactions between factors were examined graphically.

When parametric statistical procedures were applied, we tested for violations of the underlying assumptions. If the restrictive assumptions of these procedures were seriously violated, we attempted to correct the problem by applying an appropriate mathematical transformation. For example, variances associated with the mean abundances of nekton were not always homogeneous among samples from different tidal stages. This problem usually was corrected by applying a logarithmic $\left[\log _{10}(x)\right.$ or $\log _{10}(x+1)$ if the data included zeros] transformation to the abundance data prior to analysis. However, we show untransformed data in the tables and figures to simplify the presentation of the results.

Nonparametric tests were used when data failed to conform to the assumptions required by parametric procedures, as was the case for nekton size distributions which were rarely normal and often bimodal. We used the Kolmogorov-Smirnov 2-sample test to compare size distributions of the dominant nekton species collected from low and high intertidal sites at each tide 
Table 2. Species composition of the total collection (60 samples of $100 \mathrm{~m}^{2}$ each) by tide stage (incoming, slack high, ebbing) and intertidal site (low and high). Values are no. of individuals

\begin{tabular}{|c|c|c|c|c|c|c|}
\hline \multirow[t]{2}{*}{ Species } & \multicolumn{2}{|c|}{ Incoming } & \multicolumn{2}{|c|}{ Slack high } & \multicolumn{2}{|c|}{ Ebbing } \\
\hline & Low & High & Low & High & Low & High \\
\hline \multicolumn{7}{|l|}{ Fishes } \\
\hline Fundulus heteroclitus & 559 & 222 & 829 & 309 & 447 & 288 \\
\hline Fundulus luciae & 117 & 226 & 138 & 168 & 250 & 408 \\
\hline Mugil cephalus & 32 & 2 & 53 & 28 & 2 & 14 \\
\hline Poecilia latipinna & 22 & 6 & 13 & 11 & 19 & 8 \\
\hline Cyprinodon variegatus & 9 & 2 & 12 & 3 & 21 & 7 \\
\hline Mugil curema & 9 & 7 & 22 & 7 & 1 & 3 \\
\hline Leiostomus xanthurus & 0 & 0 & 18 & 20 & 0 & 1 \\
\hline Gobionellus smaragdus & 6 & 2 & 12 & 0 & 10 & 1 \\
\hline Fundulus majalis & 3 & 3 & 1 & 0 & 1 & 3 \\
\hline Bairdiella chrysoura & 1 & 0 & 8 & 0 & 0 & 0 \\
\hline Evorthodus lyricus & 3 & 0 & 1 & 1 & 2 & 0 \\
\hline Elops saurus & 0 & 0 & 3 & 3 & 0 & 0 \\
\hline Myrophis punctatus & 0 & 0 & 5 & 0 & 0 & 0 \\
\hline Menidia menidia & 0 & 0 & 3 & 0 & 0 & 0 \\
\hline Dormitator maculatus & 0 & 0 & 0 & 2 & 0 & 1 \\
\hline Gobionellus boleosoma & 0 & 0 & 1 & 0 & 1 & 0 \\
\hline Anchoa mitchilli & 0 & 0 & 1 & 0 & 0 & 0 \\
\hline \multicolumn{7}{|l|}{ Decapod crustaceans } \\
\hline Palaemonetes pugio & 944 & 141 & 1946 & 332 & 957 & 65 \\
\hline Penaeus setiferus & 177 & 63 & 349 & 99 & 69 & 81 \\
\hline Callinectes sapidus & 5 & 0 & 2 & 0 & 3 & 0 \\
\hline Alpheus heterochaelis & 0 & 0 & 2 & 0 & 1 & 0 \\
\hline
\end{tabular}

stage and between all paired combinations of tide stage at each site.

\section{RESULTS}

The 60 flume weir samples included 9627 individuals distributed among 17 species of fishes and 4 species of decapod crustaceans (Table 2). Dominant species included mummichog Fundulus heteroclitus and spotfin killifish F. luciae, which together accounted for
$90.2 \%$ of all fish, and daggerblade grass shrimp Palaemonetes pugio and white shrimp Penaeus setiferus, which composed $99.8 \%$ of the decapod crustaceans.

More species of nekton were on the marsh surface at slack high tide than at either of the other tide stages (Table 3 ). In addition to the effect of tide stage, the 2-way ANOVA detected an effect of sampling week on species richness, but an a posteriori Student-Newman-Keuls procedure failed to distinguish a difference among the weekly means (Table 3 ). Both species richness and abundance of nekton differed between intertidal sites (Table 4). More species were captured and most were more abundant at the low site. Fundulus luciae was the only dominant species with greater densities at the high site (Table 4, Fig. 1).

There was little temporal variation in the total abundance of nekton during the study (Fig. 1) and no strong evidence for an effect of sampling week on the abundance of the dominant resident species in the marsh (Table 5, Fig. 1). However, mean numbers of Penaeus setiferus and some of the seasonally abundant subdominant species like the striped mullet Mugil cephalus (Fig. 1) were significantly different across sampling weeks (Table 5). These differences seemed to occur because greater numbers of individuals were collected in weeks with more night samples (Table 1 ).

When the separate and combined effects of tide stage, site and sampling week on total abundance of nekton were examined in a 3-way ANOVA, the only significant effect was due to site (ANOVA $F, p<0.001$ ). However, when individual species were considered separately, the influence of the other factors became

Table 3. Summary results of 2-way analysis of variance and subsequent Student-Newman-Keuls (SNK) procedure testing for effects of tide stage (Tide) and sampling week (Week) on species richness. The response variable was the total number of species captured on each sampling date (low and high intertidal sites were combined). Significance of the $F$-value associated with each main factor and interaction is indicated as: $n s$, not significant $(p>0.05) ; \cdots p \leq 0.001 ; p \leq 0.05$. df: degrees of freedom. Means are shown \pm SE with $n=10$ for each tide stage and $n=6$ for each sampling week. Mean in bold type is significantly different from the other means within that same group

\begin{tabular}{|c|c|c|c|c|c|c|c|}
\hline Source of variation & df & Significance of $F$ & \multicolumn{5}{|c|}{ Results of SNK procedure $(\alpha=0.05)$} \\
\hline Tide & 2 & $\cdots$ & \multicolumn{5}{|c|}{ Tide } \\
\hline Week & 4 & $\cdot$ & & $\begin{array}{l}\text { coming } \\
\pm 0.50\end{array}$ & $\begin{array}{l}\text { Slack high } \\
9.1 \pm 0.55\end{array}$ & \multicolumn{2}{|c|}{$\begin{array}{c}\text { Ebbing } \\
5.9 \pm 0.48\end{array}$} \\
\hline Tide $\times$ Week & 8 & ns & & & Week & & \\
\hline Residual & 15 & - & $10-16$ Jun & 23-29 Jun & $11-16 \mathrm{Jul}$ & $23-29 \mathrm{Jul}$ & 8-13 Aug \\
\hline Total & 29 & - & $6.0 \pm 0.73$ & $8.7 \pm 1.17$ & $7.3 \pm 0.80$ & $7.8 \pm 0.48$ & $7.5 \pm 0.43$ \\
\hline
\end{tabular}


Table 4. Results of paired t-tests comparing species richness and nekton abundance at low and high intertidal sites during each tide stage. Values are means $\pm \mathrm{SE}, \mathrm{n}=30$

\begin{tabular}{|lccc|}
\hline Species & Low site & High site & $\begin{array}{c}\text { 2-tail } \\
\text { probability }\end{array}$ \\
\hline & \multicolumn{3}{c}{$\begin{array}{c}\text { Species richness } \\
\text { (no. of species sample }\end{array}$} \\
& $6.7 \pm 0.35$ & $4.5 \pm 0.29$ & $\mathrm{p} \leq 0.001$ \\
& \multicolumn{4}{c}{ Abundance } \\
(no. of ind. sample & \\
Fundulus heteroclitus & $61.2 \pm 8.74$ & $27.3 \pm 3.54$ & $\mathrm{p} \leq 0.001$ \\
Fundulus luciae & $16.8 \pm 2.54$ & $26.7 \pm 3.86$ & $\mathrm{p}=0.014$ \\
Palaemonetes pugio & $128.1 \pm 22.50$ & $17.9 \pm 7.84$ & $\mathrm{p} \leq 0.001$ \\
Penaeus setiferus & $19.8 \pm 5.02$ & $8.1 \pm 2.58$ & $\mathrm{p}=0.020$ \\
All other species & $10.3 \pm 1.84$ & $4.5 \pm 1.11$ & $\mathrm{p} \leq 0.001$ \\
& \multicolumn{4}{c}{} & \\
\hline
\end{tabular}

The size distributions of the dominant species differed between sites during at least one of the tidal stages, and all of the dominants exhibited significant differences in size distributions at slack high tide (Table 7). In most cases, these differences seemed to result from a greater proportion of small individuals in samples from the low, compared to the high, intertidal site (Figs. 4 \& 5). Contrary to the pattern observed in the other species, smaller individuals of Fundulus luciae were disproportionately more abundant in samples from the high intertidal at slack high tide (Fig. 4).

Size distributions of the dominants also changed with tide stage at one or evident (Table 5). Fundulus heteroclitus was the only species whose abundance was apparently unaffected by the stage of the tide (Tables $5 \& 6$ ). When there was a tide stage effect on abundance, it was usually because numbers were greater at slack high than at either the incoming or ebbing stages of the tide (Table 6). The only exception was $F$ luciae which was more abundant in ebbing tide samples than in those from either of the other 2 tidal stages. Tide stage effects on the number of Palaemonetes pugio in the samples were unclear and occurred only within a complex 3-way interaction between tide stage, elevation and sampling week (Table 5, Fig. 2). The tide stage effect on abundance of Penaeus setiferus was complicated by an interaction with sampling week (Table 5, Fig. 3). In weeks when all samples were collected during the day (Weeks 1, 3 \& 5), Penaeus setiferus was more abundant on the marsh at slack high tide than at either of the other tidal stages, as were other species (Table 6). However, in Weeks $2 \&$ 4 when several samples were collected at night, white shrimp were sometimes as abundant or even more abundant on incoming than at slack high (Fig. 3). The number of white shrimp captured on ebbing tides at night was highly variable. Shrimp were abundant at that tide stage in Week 4 , but not in Week 2.
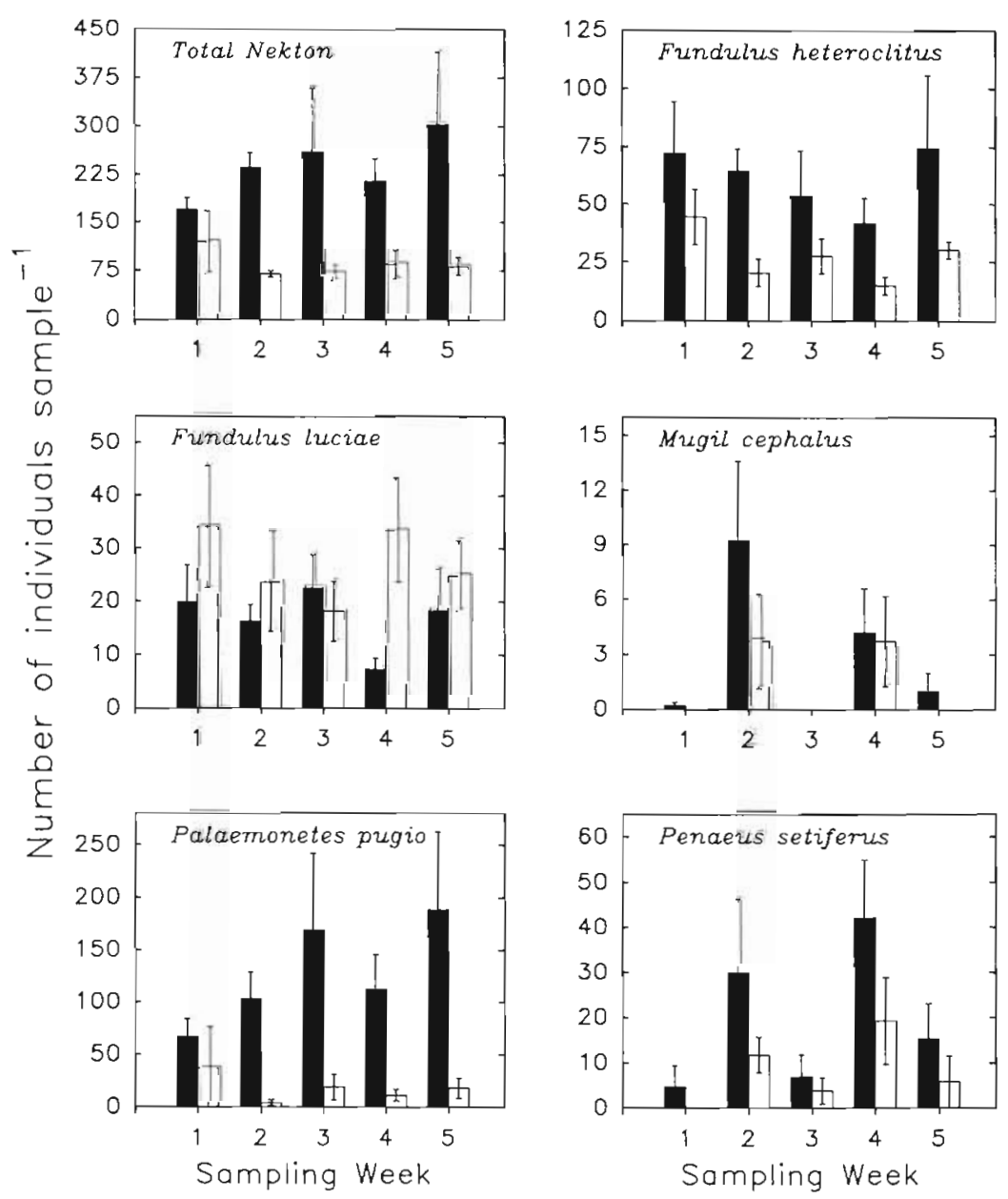

Low intertidal

High intertidal

Fig. 1. Mean ( $\pm \mathrm{SE}, \mathrm{n}=6$ ) no. of individuals captured in flume weir samples from low and high intertidal sites by sampling week: $1=10-16 \mathrm{Jun} ; 2=23-29 \mathrm{Jun}$; $3=11-16 \mathrm{Jul} ; 4=23-29 \mathrm{Jul} ; 5=8-13 \mathrm{Aug}$ 
Table 5. Summary results of 3-way ANOVA comparing effects of tide stage (Tide), intertidal site (Site) and sampling week (Week) on mean abundance of nekton in the flume weir samples. Significance of the $F$-value associated with each main factor and interaction term is indicated as: $n s$, not significant $(p>0.05) ; \cdots p \leq 0.001 ; \cdots p \leq 0.01 ; p \leq 0.05$. df: degrees of freedom. ${ }^{2}$ Data transformed by $\log _{10}(x)$; ${ }^{b}$ data transformed by $\log _{10}(x+1)$

\begin{tabular}{|c|c|c|c|c|c|c|}
\hline Source of variation & $\mathrm{df}$ & $\begin{array}{c}\text { Fundulus } \\
\text { heteroclitus }\end{array}$ & $\begin{array}{l}\text { Fundulus } \\
\text { luciae }\end{array}$ & $\begin{array}{c}\text { Palaemonetes } \\
\text { pugio }\end{array}$ & $\begin{array}{l}\text { Penaeus } \\
\text { setiferus }\end{array}$ & $\begin{array}{l}\text { All other } \\
\text { species }^{b}\end{array}$ \\
\hline Tide & 2 & ns & $\cdots$ & ns & $\cdots$ & $\cdots$ \\
\hline Site & 1 & $\cdots$ & $\cdot$ & $\cdots$ & $\cdot$ & $\cdots$ \\
\hline Week & 4 & ns & ns & ns & $\cdots$ & $\cdots$ \\
\hline Tide $\times$ Site & 2 & ns & ns & ns & ns & ns \\
\hline Tide $\times$ Week & 8 & ns & ns & ns & $\cdots$ & ns \\
\hline Site $\times$ Week & 4 & ns & ns & ns & ns & ns \\
\hline Tide $\times$ Site $\times$ Week & 8 & ns & ns & $\cdot$ & ns & ns \\
\hline Residual & 30 & - & - & - & - & - \\
\hline Total & 59 & - & - & - & - & - \\
\hline
\end{tabular}

both of the intertidal sites (Table 8), but the pattern of change was species-specific (Figs. 4 \& 5). The

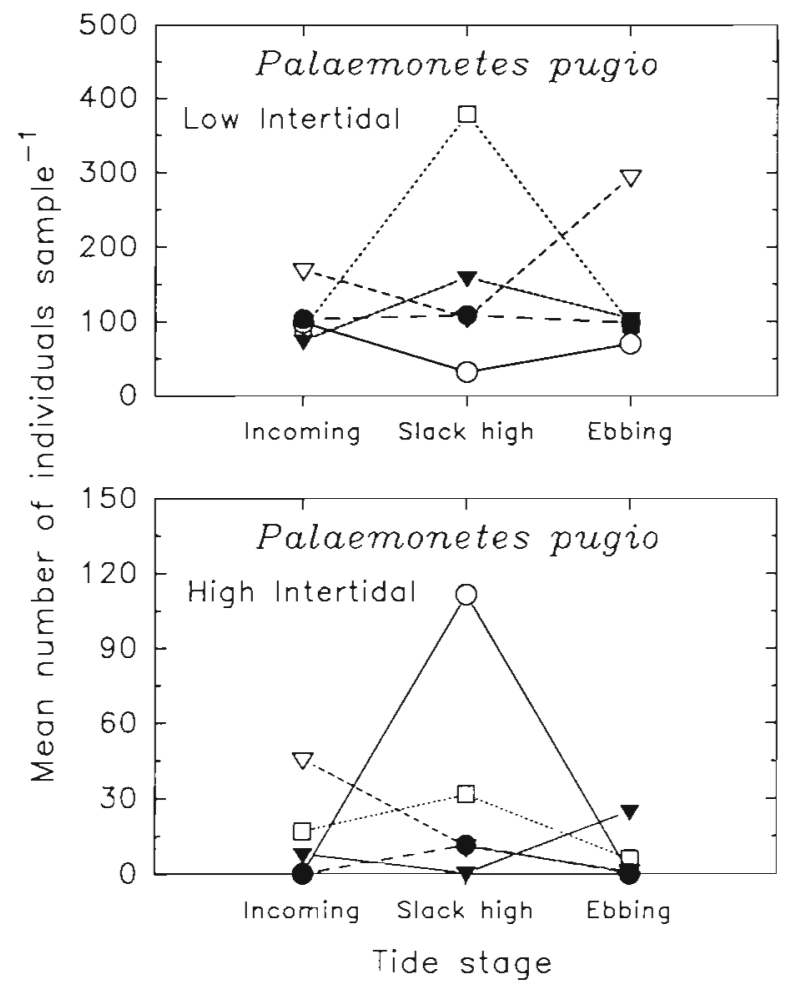

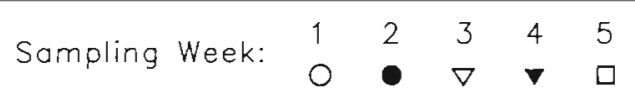

Fig. 2. Palaemonetes pugio. Graphic representation of the combined effects of tide stage, intertidal site and sampling week (significant 3-way interaction from Table 5) on the abundance of grass shrimp in the flume weir samples. Sampling weeks as in Fig. 1 common resident fish species had bimodal size distributions with most size classes present at all tidal stages (Fig. 4). Adult Fundulus heteroclitus (>30 mm $\mathrm{SL})$ were abundant whenever the marsh was flooded. Juveniles ( $\leq 30 \mathrm{~mm} \mathrm{SL})$, which were least prevalent during incoming tides, increased in relative importance with the progression of the tidal cycle so that, by the ebbing tide, immature and adult size classes were almost equally represented in the samples. In contrast, adult $F$. luciae $(>20 \mathrm{~mm}$ SL) were less prevalent relative to the juvenile size class $(\leq 20 \mathrm{~mm}$ SL) at slack high than at incoming or ebbing tide stages.

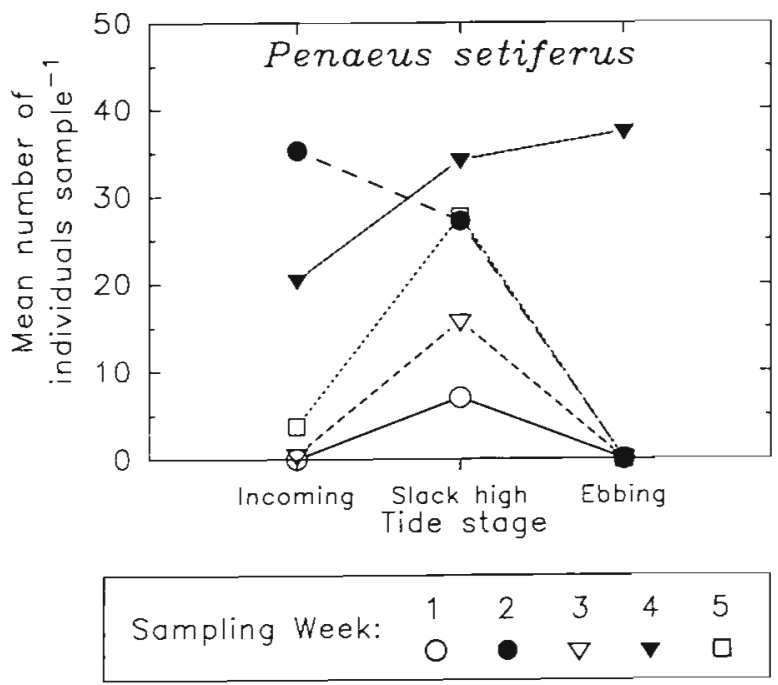

Fig. 3. Penaeus setiferus. Graphic representation of the combined effects of tide stage and sampling week (significant 2-way interaction from Table 5) on the abundance of white shrimp in the flume weir samples. Sampling weeks as in Fig. 1 
Table 6. Effect of tide stage (incoming, slack high, ebbing) on mean abundance of nekton in flume weir samples. Values are means $( \pm \mathrm{SE})$ based on pooled data from low and high intertidal sites. Means in bold type are significantly different from the other means for the same species (StudentNewman-Keuls test, $\alpha=0.05, n=20$ )

\begin{tabular}{|lccc|}
\hline Species & Incoming & Slack high & Ebbing \\
\hline Fundulus heteroclitus & $39.0 \pm 6.79$ & $56.9 \pm 13.18$ & $36.8 \pm 4.04$ \\
Fundulus luciae & $17.2 \pm 3.24$ & $15.3 \pm 3.98$ & $\mathbf{3 2 . 9 \pm 4 . 0 7}$ \\
Palaemonetes pugio & $54.2 \pm 13.96$ & $113.9 \pm 36.12$ & $51.0 \pm 12.15$ \\
Penaeus setiferus & $12.0 \pm 5.45$ & $\mathbf{2 2 . 4} \pm 5.22$ & $7.5 \pm 3.91$ \\
All other species & $5.6 \pm 2.07$ & $\mathbf{1 1 . 6} \pm \mathbf{2 . 2 5}$ & $5.0 \pm 1.05$ \\
\hline
\end{tabular}

Table 7. Results of Kolmogorov-Smirnov tests comparing size distributions of the dominant species at low and high intertidal sites. Separate comparisons were made for each tide stage. The probability that observed differences in size distributions were the result of chance alone is shown as: ns, not significant $(p>0.05) ; \cdots p \leq 0.001 ; \cdot p \leq 0.05$

\begin{tabular}{|lcccc|}
\hline Tide stage & $\begin{array}{c}\text { Fundulus } \\
\text { heteroclitus }\end{array}$ & $\begin{array}{c}\text { Fundulus } \\
\text { luciae }\end{array}$ & $\begin{array}{c}\text { Palaemonetes } \\
\text { pugio }\end{array}$ & $\begin{array}{c}\text { Penaeus } \\
\text { setiferus }\end{array}$ \\
\hline Incoming & $\mathrm{ns}$ & $\mathrm{ns}$ & $\mathrm{ns}$ & $\ldots$ \\
Slack high & $\ldots$ & $\ldots$ & $\ldots$ &.. \\
Ebbing & $\mathrm{ns}$ & $\cdot$ & $\ldots$ & $\mathrm{ns}$ \\
\hline
\end{tabular}

Not all individuals trapped within the flume weir entered the sampling pits as the tide receded. Some found low tide refuges by burrowing in the substratum or occupying small natural pools and puddles of residual tidal water that remained on the marsh surface at low tide. Although removal efficiency can be increased by leaving the flume weir panels in place (thereby preventing additional nekton from entering the sampling area) and collecting the remaining nekton in a series of retrieves following subsequent flooding tides (Kneib 1991), the frequency of our sampling precluded more than a single retrieve per sample. For single retrieve samples, species-specific flume weir efficiencies were between 42 and $97 \%$ for individuals $\geq 15 \mathrm{~mm}$ TL (Kneib 1991). For some species, such as the white shrimp Penaeus setiferus, which were recovered with a high efficiency on a single retrieve, the number captured was an accurate reflection of density (ind. $100 \mathrm{~m}^{-2}$ ). For others, such as the daggerblade grass shrimp Palaemonetes pugio, the number recovered from a single

The decapod crustaceans also had contrasting size distributions during the tide cycle (Fig. 5). Relative to adult size classes, juveniles of Palaemonetes pugio $(<20 \mathrm{~mm}$ TL) were most abundant at slack high tide and at the low intertidal site. At the high intertidal site, large individuals become more prevalent in the samples as the tidal cycle progressed from the incoming to ebbing stage. All Penaeus setiferus collected were juveniles, but their size distributions differed among tide stages and between sites. At the low intertidal site, shrimp $<60 \mathrm{~mm}$ TL predominated on incoming and ebbing tides, but larger individuals were relatively more abundant at slack high tide and on the incoming tide at the high site. At both intertidal sites smaller size classes were prominent during the ebbing tides.

\section{DISCUSSION}

There are constraints on our data that we believe should be noted at the outset. All of our samples were collected during periods of high tidal amplitude (i.e. spring tides) to ensure maximum availability of the intertidal zone to nekton; habitat use patterns may differ during neap tides. We caution that the numbers of individuals collected may not reflect actual densities because efficiency of nekton removal from the sampling area was size- and species-specific (Kneib 1991). retrieve may have been less than half of the individuals actually enclosed by the flume weir. Consequently, we used the term abundance instead of density when referring to the number of individuals collected and emphasized comparisons of species-specific patterns of relative abundance in this study.

\section{Spatial extent of marsh use by nekton}

Data on variation in species composition and abundance of nekton in salt marsh vegetation at high tide are uncommon and most studies have been restricted to within $25 \mathrm{~m}$ of the marsh edge (e.g. Hettler 1989 , Minello \& Zimmerman 1992, Rakocinski et al. 1992, Rozas \& Reed 1993). Our study focused on sites $\geq 25 \mathrm{~m}$ from the nearest creek channel and so measured the extent to which different species and size classes of nekton used the interior habitats of the vegetated intertidal marsh on spring high tides.

Surface area of the Duplin River is $1.66 \mathrm{~km}^{2}$ at low tide (Ragotzkie \& Bryson 1955), but the area inundated on spring high tides includes $90 \%$ of the intertidal drainage or ca $16 \mathrm{~km}^{2}$ of marsh (Wadsworth 1980). Although the habitat potentially available to nekton within this drainage expands 10-fold during spring high tides, few species took full advantage of foraging opportunities in the vegetated marsh. Over 75 species 

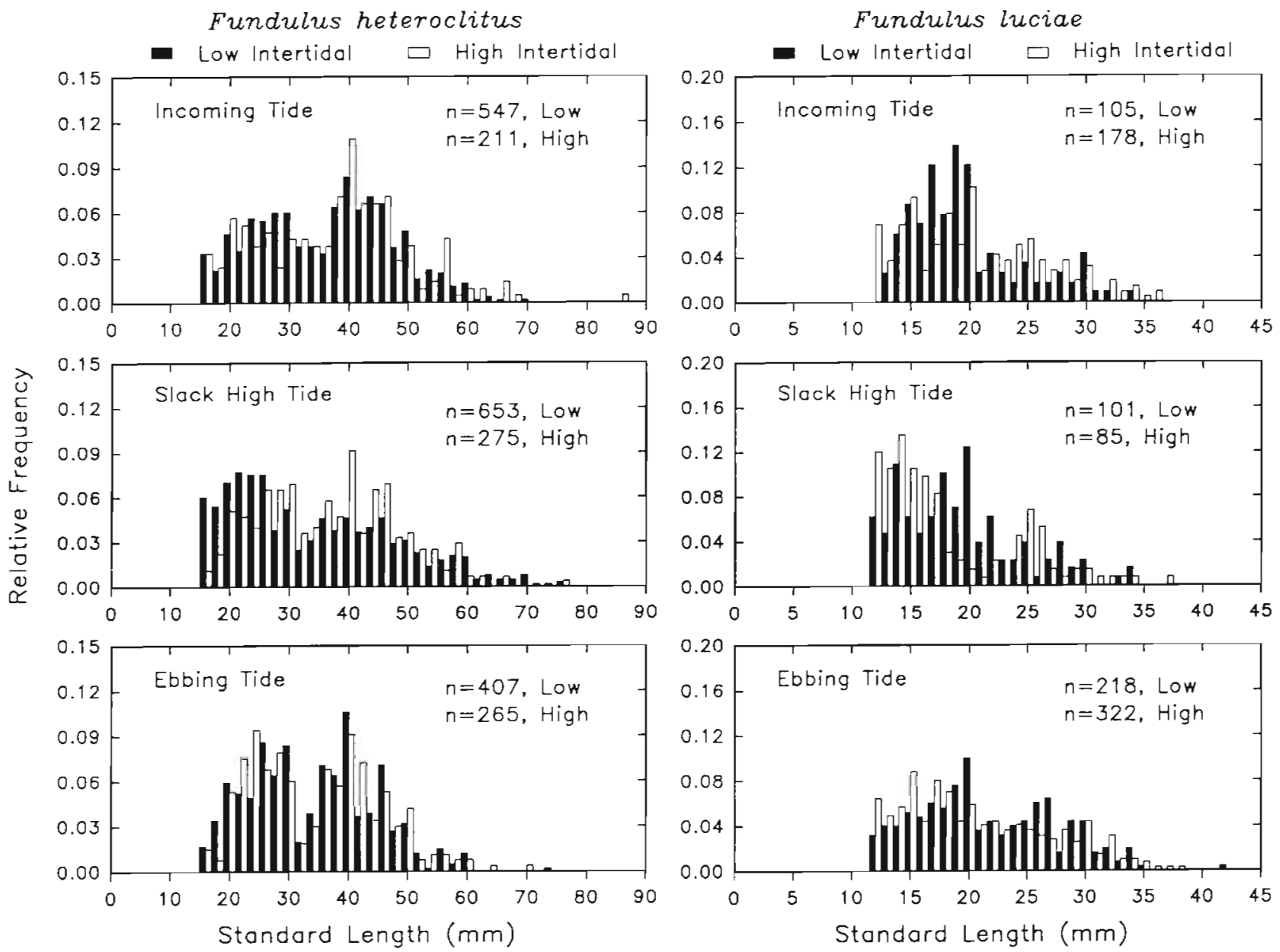

Fig. 4. Fundulus heteroclitus, F. luciae. Size distributions of the dominant fish species in the flume weir samples from low and high intertidal sites at each tide stage. Only individuals $\geq 12 \mathrm{~mm}$ SL ( $\geq 15 \mathrm{~mm} \mathrm{TL}$ ) were included

of fishes, shrimps and swimming crabs reside in the estuaries around Sapelo Island (Dahlberg \& Odum 1970, Dahlberg 1975) but we collected only 21 species and 4 of these comprised $95 \%$ of all individuals. An additional 433 flume weir samples collected in all seasons, and including other vegetated marsh locations around Sapelo Island, contained a total of 33 species, with most represented by only 1 or 2 individuals (Kneib 1991, Kneib unpubl, data). Some species, including the flatfishes Etropus crossotus and Symphurus plagiusa and many larger predatory sciaenids such as Cynoscion regalis and Micropogonias undulatus, were abundant in adjacent subtidal habitats of the estuary during the summer (Dahlberg \& Odum 1970, Reichert $\&$ van der Veer 1991), but were rare or absent in our samples. These species probably do not forage extensively beyond the edges of the vegetated marshes around Sapelo Island.

Gibson (1988) suggested that the spatial extent of intertidal habitat use by most fish species is probably related to their individual locomotive abilities as modified by features of the habitat and a variety of behavioral mechanisms associated with homing responses and territoriality. The greater species richness and abundance of nekton in our samples from the low (25 $\mathrm{m}$ from creek) compared to the high $190 \mathrm{~m}$ from creek) intertidal site suggested that many fishes and crustaceans found within the flooded marsh did not venture far into the intertidal vegetation. Other studies of intertidal habitat use by nekton in marshes of the southeastern U.S. (e.g. Cain \& Dean 1976, Rey et al. 1990, Minello \& Zimmerman 1992, Rakocinski et al. 1992, Rozas \& Reed 1993) found more species and higher abundances of fishes and crustaceans, but the samples were restricted to channels and embayments adjacent to intertidal vegetation or marsh edge habitats within $25 \mathrm{~m}$ of open water.

Many of the methods commonly used to estimate intertidal densities of nekton fail to consider the spatial extent to which species or size classes use the entire 

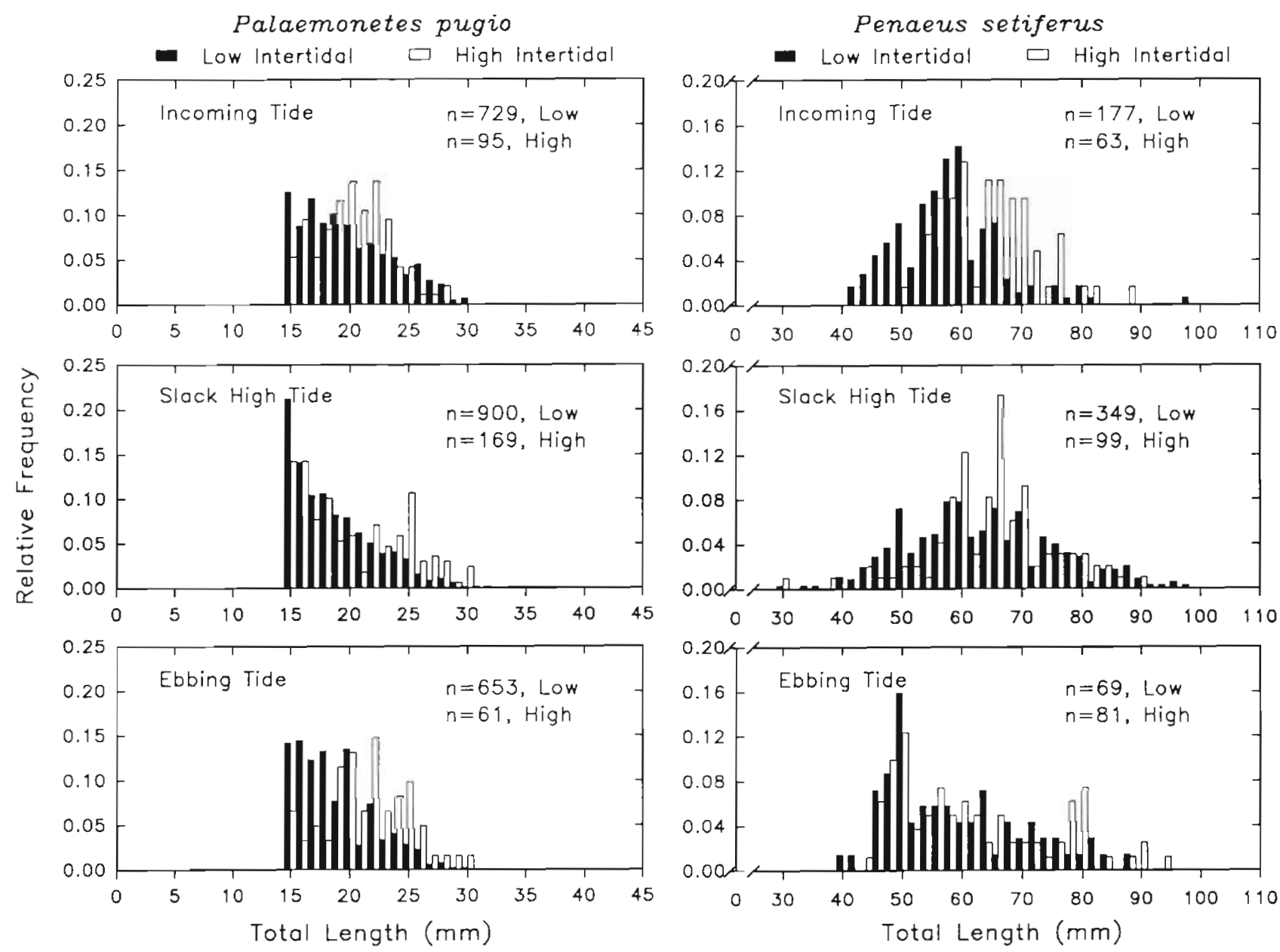

Fig. 5. Palaemonetes pugio, Penaeus setiferus. Size distributions of the dominant decapod crustaceans in the flume weir samples from low and high intertidal sites at each tide stage. Only individuals $\geq 15 \mathrm{~mm}$ TL were included

intertidal zone and may result in seriously biased estimates of nekton impacts in different habitats. Our data showed that no species was evenly distributed across the intertidal marsh at high tide and most were more abundant at the low site nearest the creekbank (Table 4). When nekton are collected from block net samples set in drainage channels (e.g. Fitz \& Wiegert 1991) or near the marsh edge (e.g. Hettler 1989) the resultant densities, expressed as numbers unit ${ }^{-1}$ of intertidal drainage area, are almost certainly underestimates of marsh edge use and overestimates of marsh interior use by nekton. Other methods may accurately assess instantaneous densities within a few meters of the marsh edge (e.g. Minello \& Zimmerman 1992, Rozas \& Reed 1993) but, if used to extrapolate densities over the entire marsh, would likely overestimate abun- dance in marsh interior habitats. Our study also showed that densities estimated from instantaneous samples in

Table 8 . Results of Kolmogorov-Smirnov tests comparing size distributions of the dominant species between different pairs of tide stages. Separate comparisons were made for low and high intertidal sites. The probability that observed differences in distributions were the result of chance alone is shown as: ns, not significant $(p>0.05)_{i} \cdots p \leq 0.001 ; \cdot p \leq 0.05$

\begin{tabular}{|c|c|c|c|c|c|c|c|c|}
\hline \multirow[t]{2}{*}{$\begin{array}{l}\text { Pairwise } \\
\text { comparison }\end{array}$} & \multirow{2}{*}{\multicolumn{2}{|c|}{$\begin{array}{l}\text { Fundulus } \\
\text { heteroclitus } \\
\text { Low High }\end{array}$}} & \multicolumn{2}{|c|}{$\begin{array}{l}\text { Fundulus } \\
\text { luciae }\end{array}$} & \multicolumn{2}{|c|}{$\begin{array}{c}\text { Palaemonetes } \\
\text { pugio }\end{array}$} & \multicolumn{2}{|c|}{$\begin{array}{l}\text { Penaeus } \\
\text { setiferus }\end{array}$} \\
\hline & & & Low & High & Low & High & Low & High \\
\hline $\begin{array}{l}\text { Incoming and } \\
\text { Slack high }\end{array}$ & $\cdots$ & ns & ns & $\cdots$ & $\cdots$ & • & $\cdots$ & ns \\
\hline $\begin{array}{l}\text { Slack high and } \\
\text { Ebbing }\end{array}$ & $\cdots$ & ns & $\cdots$ & $\cdots$ & - & ". & $\cdot$ & $\cdots$ \\
\hline $\begin{array}{l}\text { Incoming and } \\
\text { Ebbing }\end{array}$ & $\cdots$ & 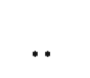 & $\cdots$ & ns & $\cdots$ & ns & ns & $\cdots$ \\
\hline
\end{tabular}


any intertidal habitat must be evalulated in terms of tidal variation in nekton use patterns.

\section{Tide stage and habitat use by nekton}

Samples collected at slack high tide generally included more species and more individuals than those taken at either of the other tide stages. This suggested that not all species arrived or departed the intertidal marsh at the same time during the tide cycle but maximum use of the marsh by nekton occurred at or around slack high tide. Previous studies have suggested that availability of suitable low tide habitat can influence the composition and abundance of nekton assemblages in intertidal marshes at high tide (Rozas \& Odum 1987, McIvor \& Odum 1988). If this hypothesis is modified to include the time required by each species to traverse the distance between its preferred low tide habitat and the intertidal marsh surface, it may also explain much of the temporal variation that occurs during the tidal cycle. Fundulus heteroclitus, F. luciae and Palaemonetes pugio were abundant in the vegetated marsh whenever it was tidally inundated, suggesting that their preferred habitat at low tide was not far from the sampling sites. Creek channels in the study area were intertidal and drained at low tide to form a series of shallow (0.1 to $1 \mathrm{~m}$ deep) pools sometimes connected only by a few $\mathrm{mm}$ of running water. This habitat, immedately adjacent to the emergent marsh, is where most of the common resident marsh fishes and crustaceans can be found at low tide. Other species, including white shrimp Penaeus setiferus, were rarely found in these intertidal creek pools at low tide and probably moved with the ebbing tide to subtidal habitats in the lower reaches of the creek channels. During flood tide, these species must migrate further up the creek channels before finding their way onto the inundated marsh surface and so arrive later in the tidal cycle than do intertidal resident species. Also, the migrants may be less tolerant to the risk of stranding in the intertidal zone and so leave the marsh earlier during the ebb tide. Consequently, species such as Penaeus setiferus do not maximize foraging time in the vegetated marsh.

White shrimp responses to tide stage were complicated by an interaction with sampling week (Fig. 3) that suggested shrimp were more abundant on the marsh at night. This may reflect a diurnal and tidal activity pattern similar to that observed in other penaeid shrimps, which are more active during night high tides than at other combinations of tidal and daynight cycles (Vance 1992). Day-night differences in the abundance of many crustaceans and fishes collected from submerged seagrass and salt marsh habitats often have been attributed to avoidance of natural predators (e.g. Greening \& Livingston 1982, Baelde 1990, Rountree \& Able 1993) or collecting gear (Leber \& Greening 1986). Gear avoidance seems an unlikely explanation for the apparent day-night differences in white shrimp abundance observed here because our sampling method was relatively unobtrusive. Although diurnal activity patterns that allow nekton to forage in relative safety from visually oriented predators is an intuitively satisfying explanation for greater night densities of shrimp in subtidal habitats, it is less appealing when applied to species that forage intertidally because so many foraging opportunities (i.e. high tides during the day) would be lost. This is especially true in the summer when days are longer and fewer of the high tides occur at night. However, at present, we are unable to provide a reasonable alternative hypothesis for the greater numbers of white shrimp in weeks when most samples were collected at night.

Temporal changes in abundance of grass shrimp Palaemonetes pugio were even more complex (Fig. 2). At the high intertidal site, grass shrimp were most abundant when white shrimp were least abundant. Although both species were always more abundant at the low intertidal site, larger white shrimp were relatively more abundant at the high site. Grass shrimp are attracted to structurally complex habitats and shift their distribution away from areas occupied by larger predators (Everett \& Ruiz 1993). We suggest that grass shrimp may have responded to a combination of factors and interactions with other species and, in particular, tended to avoid areas where the larger white shrimp were abundant. Additional research into the potential interaction between these shrimp species is indicated

Size distributions at slack high tide showed that there were proportionally more small individuals of all species, except Fundulus luciae, at the lower, deeper site nearer the creek. This was interesting because during high tide the size distributions of most species, with respect to water depth, was opposite that usually observed in marsh creeks at low tide (McIvor \& Odum 1988). Also, the larger individuals of most species were among the first to reach the high site on incoming tides and often the first to leave the marsh on ebbing tides. We believe this pattern occurred because distance traversed by nekton during the tidal. cycle was directly related to size. Most small shrimp and fish found in the shallow upper reaches of intertidal creeks at low tide moved only short distances into adjacent vegetated marsh habitats at high tide. Larger nekton, found in the lower reaches of the creeks at low tide, moved past the smaller individuals during the flood portion of the tidal cycle to maximize use of potential prey resources available at higher intertidal elevations of the flooded marsh. During ebb tides larger individuals again move past the smaller nekton in 
the low intertidal marsh returning earlier to the tidal creek channels because tolerance to the risk of stranding in the intertidal zone probably decreases with increasing size. If true, this scenario suggests that nekton, especially in the smaller size classes, have a greater impact on intertidal prey assemblages in low marsh habitats. Larger individuals, because of their greater swimming abilities, penetrate farther into the vegetated marsh and may have a proportionally greater impact on high marsh prey assemblages.

\section{Transfers of marsh production by nekton populations}

The 4 dominant species Fundulus heteroclitus, F. luciae, Palaemonetes pugio and Penaeus setiferus have dissimilar potentials for transporting intertidal marsh production to other estuarine and coastal environments because of differences in life histories and intertidal migration patterns. Our findings reflected the reluctance of spotfin killifish $F$. luciae to leave the intertidal marsh and confirmed earlier suspicions (Byrne 1978, Kneib 1978) that F luciae populations were centered in the high intertidal marsh. As a permanent resident of the intertidal zone, F. luciae probably does not contribute greatly to the direct transport of intertidal production out of the salt marsh system. In contrast, white shrimp Penaeus setiferus was the only dominant species not resident year-round in Georgia salt marshes. Juveniles are abundant in Georgia estuaries from June to October (Nelson et al. 1991). Adults spawn offshore and planktonic larvae migrate or are transported by currents to inshore nurseries, where juveniles grow to adult size within a few months before migrating to the coastal ocean to spawn (Williams 1984). This species, like others that undergo largescale ontogenetic migrations (Deegan 1993), seemed to have the greatest potential to directly transport marsh production into the nearshore coastal environment, where much of the biomass produced within the estuary is available for harvest in commercial fisheries (Turner 1977). However, habitat use patterns at 2 different points along a temporal scale may diminish the amount of intertidal marsh production transferred annually by white shrimp. First, $P$. setiferus were only seasonally abundant (June to November) in intertidal marshes on Sapelo Island. Second, they arrived later and departed the flooded habitat earlier in the tidal cycle than did the other dominant species and so did not maximize available foraging time in the vegetated marsh.

The 2 most abundant species, daggerblade grass shrimp Palaemonetes pugio and common mummichog Fundulus heteroclitus, are permanent marsh residents that do not migrate between the estuary and coastal ocean. The intertidal marsh is a nursery for larval mummichogs and postlarval grass shrimp in Georgia (Kneib 1987), but the adults of both species migrate between low tide habitats at the upper reaches of tidal creek channels and the intertidal marsh with each tide. This regular pattern of tidal migration provides maximum access to foraging sites in the marsh at high tide and exposure to larger predatory fishes and crustaceans in creek channels and open water habitats adjacent to the vegetated marsh at other tidal stages (Mclvor \& Odum 1988, Rountree \& Able 1992).

Many of the potential predators common in marsh creeks of the southeastern U.S., including Cynoscion spp., Morone saxatilis, Anguilla rostrata, Pomatomus saltatrix, Leiostomus xanthurus, Micropogonias undulatus, Paralichthys spp., Sciaenops ocellatus and Callinectes sapidus, migrate extensively within estuaries and into the coastal ocean. In their role as prey for these species, Fundulus heteroclitus and Palaemonetes pugio may provide the most important trophic links between the intertidal marsh and open estuarine waters.

Acknowledgements. We thank M. Covi and J. Senter for their help with field sampling. C. Rejwan assisted with sample processing in the laboratory and J. Parker was instrumental in collecting and processing information from the electronic data loggers. Dr L. Barbieri, J. Parker and 2 anonymous reviewers provided helpful suggestions for improving the manuscript. Financial support for S.L.W. was provided by the Sapelo Island Research Foundation through The University of Georgia Marine Institute Student Intern Program. This work is the result of research sponsored by the NOAA Office of Sea Grant, U.S. Dept of Commerce (Grant no. NA88AA-DSG098). This paper is Contribution No. 742 of the University of Georgia Marine Institute.

\section{LITERATURE CITED}

Ayvazian, S. G., Deegan, L. A., Finn, J. T. (1992). Comparison of habitat use by estuarine fish assemblages in the Acadian and Virginian zoogeographic provinces. Estuaries 15: $368-383$

Baelde, P. (1990). Differences in the structures of fish assemblages in Thalassia testudinum beds in Guadeloupe, French West Indies, and their ecological significance. Mar. Biol. 105: 163-173

Byrne, D. M. (1978). Life history of the spotfin killifish, Fundulus luciae (Pisces: Cyprinodontidae), in Fox Creek Marsh, Virginia. Estuaries 1: 211-227

Cain, R. L., Dean, J. M. (1976). Annual occurrence, abundance and diversity of fish in a South Carolina intertidal creek. Mar. Biol. 36: 369-379

Dahlberg, M. D. (1975). Guide to coastal fishes of Georgia and nearby states. University of Georgia Press, Athens

Dahlberg, M. D., Odum, E. P. (1970). Annual cycles of species occurrence, abundance and diversity in Georgia estuarine fish populations. Am. Midl. Nat. 83: 382-392

Deegan, L. A. (1993). Nutrient and energy transport between estuaries and coastal marine ecosystems by fish migration. Can. J. Fish. Aquat. Sci. 50:74-79 
Everett, R. A., Ruiz, G. M. (1993). Coarse woody debris as a refuge from predation in aquatic communities: an experimental test. Oecologia 93: 475-486

Ferrell, D. J., Bell, J. D. (1991). Differences among assemblages of fish associated with Zostera capricorni and bare sand over a large spatial scale. Mar. Ecol. Prog. Ser. 72: $15-24$

Fitz, H. C., Wiegert, R. G. (1991). Utilization of the intertidal zone of a salt marsh by the blue crab Callinectes sapidus: density, return frequency, and feeding habits. Mar. Ecol. Prog. Ser. 76: 249-260

Flores-Verdugo, F., González-Farías, F, Ramírez-Flores, O., Amezcua Linares, F., Yáñez-Arancibia, A., Alvarez-Rubio, M., Day, J. W. Jr (1990). Mangrove ecology, aquatic primary productivity, and fish community dynamics in the Teacapán-Agua Brava lagoon-estuarine system (Mexican Parific). Estuaries 13: 219-230

Gibson, R. N. (1988). Patterns of movement in intertidal fishes. In: Chelazzi, G., Vannini, M. (eds.) Behavioral adaptation to intertidal life. Plenum Publishing Corp., New York, p. 55-63

Greening, H. S., Livingston, R. J. (1982). Diel variation in the structure of seagrass-associated epibenthic macroinvertebrate communities. Mar. Ecol. Prog. Ser. 7: 147-156

Heck, K. L. Jr, Thoman, T. A. (1984). The nursery role of seagrass meadows in the upper and lower reaches of the Chesapeake Bay. Estuaries 7: 70-92

Hettler, W. F. Jr (1989). Nekton use of regularly flooded saltmarsh cordgrass habitat in North Carolina, USA. Mar. Ecol. Prog. Ser. 56: 111-118

Kneib, R. T. (1978). Habitat, diet, reproduction and growth of the spotfin killifish, Fundulus luciae, from a North Carolina salt marsh. Copeia 1978: 164-168

Kneib, R. T (1984). Patterns of invertebrate distribution and abundance in the intertidal salt marsh: causes and questions. Estuaries 7(A): 392412

Kneib, R. T. (1987). Predation risk and use of intertidal habitats by young fishes and shrimp. Ecology 68: 379-386

Kneib, R. T. (1991). Flume weir for quantitative collection of nekton from vegetated intertidal habitats. Mar. Ecol. Prog. Ser. 75: 29-38

Leber, K. M., Greening, H. S. (1986). Community studies in seagrass meadows: a comparison of two methods for sampling macroinvertebrates and fishes. Fish. Bull. U.S. 84: $443-450$

McIvor, C. C., Odum, W. E. (1986). The flume net: a quantitative method for sampling fishes and macrocrustaceans on tidal marsh surfaces. Estuaries 9: 219-224

McIvor, C. C., Odum, W. E. (1988). Food, predation risk, and microhabitat selection in a marsh fish assemblage. Ecol. ogy 69: 1341-1351

Minello, T. J., Zimmerman, R. J. (1992). Utilization of natural and transplanted Texas salt marshes by fish and decapod crustaceans. Mar. Ecol. Prog. Ser. 90: 273-285

Morton, R. M. (1990). Community structure, density and standing crop of fishes in a subtropical Australian mangrove area. Mar. Biol. 105: 385394

Nelson, D. M., Irlandi, E. A., Settle, L. R., Monaco, M. E., Coston Clements, L. C. (1991). Distribution and abundance of fishes and invertebrates in Southeast estuaries. ELMR Rept no. 9. NOAA/NOS Strategic Environmental Assessments Division, Rockville, MD

Norušis, M. J (1990). SPSS/PC+ Statistics 4. 0 for the IBM PC/XT/AT and PS/2. (Subprogram of the Statistical Package for the Social Sciences). SPSS, Inc., Chicago

Parrish, J. D. (1989). Fish communities of interacting shallowwater habitats in tropical oceanic regions. Mar. Ecol. Prog.
Ser. 58: $143-160$

Ragotzkie, R. A., Bryson, R. A. (1955). Hydrography of the Duplin River, Sapelo Island, Georgia. Bull. mar. Sci. Gulf Caribb. 5: 297-314

Rakocinski, C. F., Baltz, D. M., Fleeger, J. W. (1992). Correspondence between environmental gradients and the community structure of marsh edge fishes in a Louisiana estuary. Mar. Ecol. Prog. Ser. 80: 135-148

Reichert, M. J. M., van der Veer, H. W. (1991). Settlement, abundance, growth and mortality of juvenile flatfish in a subtropical tidal estuary (Georgia, U.S.A.). Neth. J. Sea Res. 27: 375-391

Rey, J. R., Shaffer, J., Tremain, D., Crossman, R. A., Kain, T. (1990). Effects of re-establishing tidal connections in two impounded subtropical marshes on fishes and physical conditions. Wetlands 10:27-46

Robertson, A. I., Duke, N. C. (1987). Mangroves as nursery sites: comparisons of the abundance and species composition of fish and crustaceans in mangroves and other nearshore habitats in tropical Australia. Mar. Biol. 96: 193-205

Rountree, R. A., Able, K. W. (1992). Fauna of polyhaline subtidal marsh creeks in southern New Jersey: composition, abundance and biomass. Estuaries 15: 171-185

Rountree, R. A., Able, K.W. (1993). Diel variation in decapod crustacean and fish assemblages in New Jersey polyhaline marsh creeks. Estuar. coast. Shelf Sci. 37: 181-201

Rozas, L. P. (1992). Bottomless lift net for quantitatively sampling nekton on intertidal marshes. Mar. Ecol. Prog. Ser. 89: $287-292$

Rozas, L. P., Odum, E. P. (1987). The role of submerged aquatic vegetation in influencing the abundance of nekton on contiguous tidal fresh-water marshes. J. exp. mar. Biol. Ecol. 114: 289-300

Rozas, L. P., Reed, D. J. (1993). Nekton use of marsh-surface habitats in Louisiana (USA) deltaic salt marshes undergoing submergence. Mar. Ecol. Prog. Ser. 96: 147-157

Ryer, C. H. (1987). Temporal patterns of feeding by blue crabs (Callinectes sapidus) in a tidal-marsh creek and adjacent seagrass meadow in the lower Chesapeake Bay. Estuaries 10: $136-140$

Sokal, R. R., Rohlf, F. J. (1981). Biometry. W. H. Freeman and Co., San Francisco

Thayer, G. W., Colby, D. R., Hettler, W. F. Jr (1987). Utilization of the red mangrove prop root habitat by fishes in south Florida. Mar. Ecol. Prog. Ser. 35: 25-38

Turner, R. E. (1977). Intertidal vegetation and commercial yields of penaeid shrimp. Trans. Am. Fish. Soc. 106: $411-416$

Vance, D. J. (1992). Activity patterns of juvenile penaeid prawns in response to artificial tidal and day-night cycles: a comparison of three species. Mar. Ecol. Prog. Ser. 87 $215-226$

Wadsworth, J. R. Jr (1980). Geomorphic characteristics of tidal drainage networks in the Duplin River system. Sapelo Island, Georgia. Ph.D. dissertation, University of Georgia, Athens

Weisberg, S. B., Lotrich, V. A. (1982). The importance of an infrequently flooded intertidal marsh surface as an energy source for the mummichog Fundulus heteroclitus: an experimental approach. Mar. Biol 66: 307-310

Williams, A. B. (1984). Shrimps, lobsters, and crabs of the Atlantic coast of the eastern United States, Maine to Florida. Smithsonian Institution Press, Washington, DC

Zimmerman, R. J., Minello, T. J. (1984). Densities of Penaeus aztecus, Penaeus setiferus, and other natant macrofauna in a Texas salt marsh. Estuaries 7(4A): 421-433 